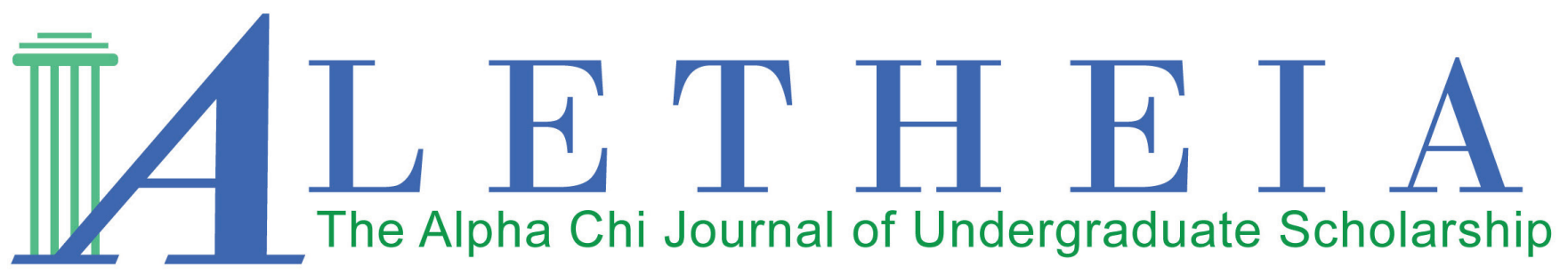

Volume 2 | Issue 1 | 2017

\title{
Zitkala Sa: A Slave to Assimilation
}

\author{
Jesse Morrow \\ Texas A\&M University-Texarkana \\ Texas Beta Alpha Chapter
}

Vol. 2(1), 2017

Article Title: Zitkala Sa: A Slave to Assimilation

DOI: $10.21081 / \mathrm{AX} 0109$

ISSN: 2381-800X

Key Words: assimilation, Native American, education, American literature, identity This work is licensed under a Creative Commons Attribution 4.0 International License. Author contact information is available from the Editor at editor@alphachihonor.org.

\section{Aletheia-The Alpha Chi Journal of Undergraduate Scholarship}

- This publication is an online, peer-reviewed, interdisciplinary undergraduate journal, whose mission is to promote high quality research and scholarship among undergraduates by showcasing exemplary work.

- Submissions can be in any basic or applied field of study, including the physical and life sciences, the social sciences, the humanities, education, engineering, and the arts.

- Publication in Aletheia will recognize students who excel academically and foster mentor/mentee relationships between faculty and students.

- In keeping with the strong tradition of student involvement in all levels of Alpha Chi, the journal will also provide a forum for students to become actively involved in the writing, peer review, and publication process.

- More information and instructions for authors is available under the publications tab at www.AlphaChiHonor.org. Questions to the editor may be directed to editor@alphachihonor.org.

\footnotetext{
Alpha Chi is a national college honor society that admits students from all academic disciplines, with membership limited to the top 10 percent of an institution's juniors, seniors, and graduate students. Invitation to membership comes only through an institutional chapter. A college seeking a chapter must grant baccalaureate degrees and be regionally accredited. Some 300 chapters, located in almost every state, induct approximately 12,000 members annually. Alpha Chi members have been "making scholarship effective for good" since 1922.
} 


\title{
Zitkala Sa: A Slave to Assimilation
}

\author{
Jesse Morrow \\ Texas A\&M University-Texarkana \\ Texas Beta Alpha Chapter
}

\begin{abstract}
Zitkala Sa's autobiographical work The School Days of an Indian Girl provides a unique perspective on the difficulties Native Americans of her time encountered while assimilating into the growing Western culture of post-colonial America. Structurally, the story offers a unique perspective on the Native American assimilation process by mirroring the traditional slave narrative, a choice that seems fitting if one considers the author as attempting to express a view of her becoming increasingly disempowered as a result of her integration into an oppressive hegemonic power structure. The reasoning behind this gesture seems perfectly plausible when one considers the psychological burdens the recorded events of the narrative have on Sa's developing mind, the various events that she is forced to endure, as well as the choice of language that Sa uses to express her ideas. As Margo Lukens, a Scholar from the University of Maine and contributor to the Online Dictionary of Literary Biography claims, "[S]he did not mince words, and her stories are emotionally charged - often angry, sometimes strident in directing accusations against white oppression of Indians" (Lukens). Such rhetorical strategies accompanied by Sa's unique mourning-tinged style allow her to convincingly articulate her deep-rooted resentment of an oppressive system from which she believes there is little chance of escaping.
\end{abstract}

Key words: assimilation, Native American, education, American literature, identity

\section{"True knowledge comes only through suffering." - Elizabeth Barrett Browning}

Zitkala Sa's autobiographical work The School Days of an Indian Girl provides a unique perspective on the difficulties Native Americans of her time encountered while assimilating into the growing Western culture of post-colonial America. Structurally, the story offers a unique perspective on the Native American assimilation process by paralleling the narrative form of what scholars such as James Olney define as the conventions of the traditional slave narrative. In his article, “I Was Born': Slave Narratives, Their Status as Autobiography and as Literature," for example, Olney suggests slave narratives frequently develop according to an outline of twelve distinct steps, which include significant plot el- ements such as an uncertain or incomplete explanation of parentage, accounts of an extraordinarily strong or rebellious slave, difficulties encountered throughout the educational process, patterns of the day, escape attempts, and reflections on slavery (50-51). The formal expression of Sa's narrative, then, seems appropriate if one considers the author as attempting to express her experience of disempowerment in the face of an oppressive hegemonic power structure, and while Sa's experiences cannot possibly be equitable to the horrors experienced by victims of chattel slavery, she may nevertheless have constructed her narrative in a fashion similar to that of the conventions of the traditional slave narrative in order to make sense of her suffering and convey the injustice of the assimilation processes demanded of Native Americans. 
Furthermore, Sa's framing her story along the lines of the traditional slave narrative seems perfectly plausible when one considers the psychological burdens the recorded events of the narrative have on Sa's developing mind, the various events that she is forced to endure, as well as the choice of language that Sa uses to express her ideas. As Margo Lukens, a Scholar from the University of Maine and contributor to the Online Dictionary of Literary Biography claims, "[S]he did not mince words, and her stories are emotionally charged - often angry, sometimes strident in directing accusations against white oppression of Indians" (Lukens). Such rhetorical strategies accompanied by Sa's unique mourning-tinged style allow her to convincingly articulate her deep-rooted resentment of an oppressive system from which she believes there is little chance of escaping.

Most of the essential elements of the slave narrative suggested by Olney are included in the story with the exception of the protagonist's achievement of absolute freedom, at least in the form of an escape from the professed tyrant at hand (the prevailing Westernization of America). Instead, Sa suggests the opposite occurs: the young Sa naively leaves a world of perpetual freedom behind and through the assimilation process ultimately enters a state of disempowerment amplified by her professed estrangement and loss of community. This unique modification of the traditional slave narrative structure makes sense when one considers that due to the conquest of American land, ill treatment of the country's native people, and the near complete genocide of the Native American people, she may have felt as though she had been forced to integrate into a seemingly oppressive master society.

Through this unique stylistic approach, the author explains how the assimilation of the Native American person into a society dominated by Western culture causes the Native American (in this case Zitkala Sa) individual psychological conflict, a devaluation of her original culture, and an overbearing sense of alienation. She expresses the consistent development of each of these issues through the three segments of her story: her departure, her indoctrination, and her return. This abbreviated structure can again be seen as a representation of a slave narrative: the slave departs from what she believes to be servitude, enters into her liberty through a cultural and economic indoctrination, and she returns (or rather reflects, which is returning in an intellectual sense) to her previous environment by revisiting her original slave state in the form of the written expression of the narrator's life story.

Sa begins her departure by leaving the tribe, an act that the reader can interpret as her subconscious belief that her culture is inferior and impeding her freedom to choose and develop as she sees fit. This concept is understandable when one considers the ways in which representatives of Western society have promised her such things as "The Land of Red Apples," "a country more beautiful than hers," and the benefit of an education (Sa 1116). Such enticements prey on the young girl's inexperience and build a misconceived notion that this new culture can offer her luxuries that her previous culture cannot. After pleading for her mother's approval, the young $\mathrm{Sa}$ is given permission to leave the tribe and sets off on the Iron Horse to the east in hopes of a better tomorrow.

The train serves as a transitional symbol for her journey from a communal society into an unfamiliar society that places the emphasis on the individual. Without realizing it, Sa has, by leaving her people, placed herself into an isolated position of exclusion: an environment that stresses the potential of the individual rather than the collective potential of the group. By forsaking her people's initial warnings and instead following her individual desire to witness the glories of Western culture, Sa has allowed the emphasis to shift from the community onto her as an individual, thus creating the initial manifestation of her developing sense of alienation.

This rapid shift in cultural emphasis on the individual causes psychological disturbances for the protagonist which readers will later see develop into an overbearing sense of anxiety. Drawing inspiration from the work of several renowned psychologists, including Janet Taylor, Sigmund Freud, and Irwin G. Sarason, Seiber et al. claim in Anxiety, Learning, and Instruction, "we may expect a high level of manifest anxiety in persons who fear separation from their parents during their childhood" (Sieber, 18-19). Without the direction of her parents, Sa finds herself shamed as the victim of a soured stomach by overindulging in what she calls sweet-meats. She is also left feeling the psychological burden of embarrassment by enduring the train passengers' constant stares, something that does not occur in her previous culture and might have been somewhat alleviated if her lost mentors were available for advice and protection.

Upon the train's night-time arrival, young Sa is led to the school grounds, bringing the departure phase to 
its conclusion and ushering in the indoctrination phase, which contains the majority of the slave narrative parallels. Sa is first greeted in a manner that upsets her greatly. She is tossed into the air as a plaything, something that she says her mother would never do. This belittling action greatly traumatizes the young Indian girl; she cannot understand how two cultures have such different expressions of compassion. Her cries only make matters worse by attracting threats from her teachers, a sign of the general educational philosophy of the school and the struggle ahead.

The indoctrination period of Sa's story contains three important events that must be considered in order to grasp the severity of the oppression that Zitkala feels: the psychological trauma brought on by the cutting of Sa's hair, the prioritization of Western culture over Sa's culture, and the sense of alienation caused by issues of conformity.

Sa describes her first day in the land of red apples as a cultural nightmare. After many uncomfortable events, $\mathrm{Sa}$ is approached by a classmate who warns her that all of the Indian girls' hair will soon be shingled. Sa is overcome with dread, saying, "Our mothers had taught us that only unskilled warriors who were captured had their hair shingled by the enemy. Among our people, short hair was worn by mourners, and shingled hair by cowards" (Sa, 1116).

When advised by her friend to submit to the stronger pale face, Sa defiantly yells "No, I will not submit! I will struggle first!" (1116). Sa's statements reinforce the reader's suspicions of the growing anxiety within the young girl and her deep desire to maintain control through the act of rebellion.

Joan E. Seiber, who has conducted a considerable amount of research into the undesirable effects of anxiety, proposes that, according to existentialist thought, "anxiety has to do with holding values, and fear that one will not measure up to them" (14). Sa is afraid that if she allows her hair to be shingled, she will not measure up to her culture's idea of bravery. She feels that while in this foreign environment she now has the responsibility of representing her culture, an idea that elevates her anxiety even further. Sieber also suggests as much when she mentions, "an individual who has just been given some important new rank and responsibility may fear that he or she will not measure up fully to that role" (14). As a means of postponing this conflict, Sa hastily flees the scene and hides under a bed. Sieber claims that such a learned response is only natural as a defense mechanism for an individual who is anxious (19).

$\mathrm{Sa}$, unfortunately, cannot remain hidden and is cruelly bound and forced to endure the haircut, thus damaging her self-image and pushing her anxiety over the edge. Sa's interpretation of the harsh circumstances surrounding the haircut, in addition to her escape, parallels three crucial elements found within a slave narrative: a cruel master or mistress mistreats a slave (Sa's forced shingling), the slave is particularly strong and proud (Sa's defiance), and a failed escape attempt (Sa's being discovered and recaptured by her oppressors).

Sa writes that her feelings of slave-like oppression were only intensified when she was educated in the classroom. She speaks of how the children were made to endure strict procedures and learning processes, a direct contrast to her previous culture's approach to learning. The way Sa describes the process implies that the teachers prioritized the indoctrination of Western ideas over that of her specific Native American culture's ideas. Furthermore, in many cases they punished any sign of nostalgia or reflection of the students' previous culture. Jeanne Campbell Reesman and Arnold Krupat point out that $\mathrm{Sa}$ and her Indian classmates were "forbidden to speak their Native Languages" (Reesman, 1105). Such teaching methods support the notion that citizens belonging to the developing Western culture of Sa's time harbored a belief in the superiority of Western culture through prioritization and punishment. Besides creating anxiety, the methods of pedagogy used during Sa's indoctrination foster a sense of animosity within the student. According to How People Learn by the National Research Council, "students come to classrooms with preconceived ideas about how the world works. If their initial understanding is not engaged they may fail to grasp the new concepts, or they may learn them for the purpose of the test but revert to their previous ideas outside the classroom" (14). The student endures lessons but does not fully assimilate the ideas, furthering the difficulty of Sa's assimilation into Western culture.

Because Sa's Western teachers opted to forgo a form of teaching that was sympathetic to Native American culture, they succeeded in worsening the relationship between the two cultures. Sa and her peers were forced to endure and submit to this indoctrination in a manner that can understandably be interpreted as similar to that of a slave submitting to the will of its uncaring master. 
Sa's resentment of the methods of the indoctrination process further amplifies her sense of alienation. Though Sa's peers may have suffered internally as she did, they were still driven to absorb the "pale face's" lessons and at the very least present themselves in a manner that feigned Westernization. Logically, the pressure to conform must have weighed heavily upon young Sa's mind. Her peers' conformity would likely result in a feeling of immense alienation; "cultural differences can affect students' comfort levels in working collaboratively verses individually, and they are reflected in the background knowledge students bring to a new learning situation" (23). Her peers' conformity coupled with the struggles of coping with assimilation into an oppressive culture made Sa feel increasingly alienated.

The educational portion of the indoctrination phase reminds the reader of the feelings of servitude young Sa resented. The harsh explanations of her regimented schedule, the descriptions of the work required of the students, and the announcements of clothing worn by fellow students all fulfill the characteristics of a traditional slave narrative and express Sa's feelings of societal and cultural slavery.

Before transitioning to her account of returning to her people, Sa summarizes her feelings of the indoctrination process by stating,

the melancholy of those black days has left so long a shadow that it darkens the path of years that have since gone by. These sad memories rise above those of smoothly grinding school days. Perhaps my Indian Nature is the moaning wind which stirs them now for their present record. But, however tempestuous this is within me, it comes but as the low voice of a curiously colored seashell, which is only for those ears that are bent with compassion to hear it. (Sa, 1117)

Sa opens the return phase of her story by blatantly stating her sense of alienation; she has a feeling of stasis, hanging in limbo between two very different cultures:

My brother...did not quite understand my feelings. My mother had never gone inside of a school-house, and so she was not capable of comforting her daughter who could read and write. Even Nature seemed to have no place for me. I was neither a wee girl nor a tall one; neither a wild Indian nor a tame one. This deplorable situation was the effect of my brief course in the east, and the unsatisfactory "teenth" in a girl's years. (1118)
Sa blames the cultural influence of, and indoctrination by, representatives of Western culture for her feelings of isolation and lack of cultural identity. One may also note that the written expression of her ability to read and write in the story provide another parallel to the traditional slave narrative, a discussion of the acquisition of literary skills.

Her appreciation for her past culture diminishes greatly as a result of her experience with Westernized cultural forms and can be seen in the actions of the indoctrinated Native American youth. Sa speaks of how the young braves no longer wear blankets around them or eagle plumes, nor do the Native American maids paint their cheeks. Their trip to the east had civilized them: "the young men wore the white man's coat and trousers, with bright neckties. The girls wore tight muslin dresses; with ribbons at neck and waist" (1119). No longer do the young Native Americans try to follow the customs of their people. Sa feels that, whether due to the white man's successful suspension of native languages and customs, or the Native American's apathetic acceptance of Western dominance, many who went east chose Western customs as superior to their previous customs. She explains how at these gatherings the youth speak English instead of their native tongue, a language that many now have difficulty speaking after so long of an absence and forced suppression.

Sa, again, shows signs of identity crisis. She refuses to wear Western clothes during her stay with her people, impeding her assimilation into the indoctrinated culture. Yet she also has difficulty fitting into her previous culture. After explaining her anguish, she recounts how her mother "offered me the only printed matter we had in our home. It was an Indian Bible, given her some years ago, by a missionary. She tried to console me 'here, my child, are the white man's papers. Read a little from them,' she said most piously" (1119). Sa then proceeds to take the Bible to comfort her mother, but reveals that inwardly her spirit is enraged and she feels like burning the book. Her contempt of Western culture causes her to reject the Bible completely, which serves as another parallel to slave narratives: reflection on religion, especially that of Christianity, and how Christian individuals and society are often the most brutal of tyrants.

The anxiety, psychological conflict, complete sense of alienation, and inability to harmoniously reconnect with her initial Native American culture causes such inner turmoil for Sa that eventually she escapes back to the 
Eastern school and in time pursues a college education, a move she perceives as her only other option. Sa writes that when she sets out for college, her mother encourages her to come back, but Sa deliberately disobeys, again paralleling the separation of family members found in slave narratives.

Thus, in her search for identity, the isolated Sa sets out "homeless and heavy-hearted...[beginning] anew [her] life among strangers" (1120). Sa, like many Native Americans who have attempted to assimilate into Western society, realizes that she is neither the product of a pure Native American culture, nor the result of a complete Western indoctrination; Sa is a fractured representation of both. With this new-found understanding of the nature of her individuality, Zitkala Sa sets out among a world of strangers to realize her own self-actualization by participating in both cultures, but finding a home in neither.

\section{Works Cited}

Sa, Zitkala. "The School days of an Indian girl" The Norton Anthology of American Literature Vol.C. Ed. Nina Baym. New York: Norton \& Company, 2007. 1113-1121. Print

Lukens, Margo. Gale Literary Database: Dictionary of Literary Biography, Volume 175: Native American Writers of the United States. A Bruccoli Clark Layman Book. Edited by Kenneth M. Roemer, University of Texas at Arlington. The Gale Group, 1997. pp. 331-336. http:// galenet.galegroup.com.dbproxy.tamut.edu

Olney, James. “'I Was Born': Slave Narratives, Their Status as Autobiography and as Literature." Callaloo, no. 20, 1984, pp. 46-73. www.jstor.org/stable/2930678.

Seiber, Joan E., Harold F. O'neal, Jr., and Sigmund Tobias. Anxiety, learning, and Instruction. Hillsdale, NJ: Lawrence Erlbaum, 1977. Print.

Committee on Developments in the Science of Learning and Committee on Learning Research and Educational Practice. How People Learn: Brain, Mind, Experience, and School. Washington, D.C.: National Academy Press, 2000. Print

Reesman, Jeanne Campbell, and Arnold Krupat. "Zitkala Sa (Gertrude Simmons Bonnin)." The Norton Anthology of American Literature Vol.C. Ed. Nina Baym. New York: Norton \& Company, 2007. 1105-1106. Print 